\begin{tabular}{|c|c|c|}
\hline GE) & 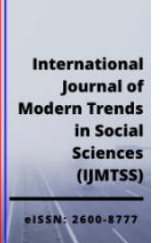 & $\begin{array}{c}\text { INTERNATIONAL JOURNAL OF } \\
\text { MODERN TRENDS IN } \\
\text { SOCIAL SCIENCES } \\
\text { (IJMTSS) }\end{array}$ \\
\hline
\end{tabular}

\title{
RHETORICAL STRATEGIES USED IN MALAY RESEARCH ARTICLE CONCLUSIONS
}

\author{
Loi Chek Kim ${ }^{1 *}$, Lau Yoke $\operatorname{Lian}^{2}$, Soon Chow Thai ${ }^{3}$, Nur Shafiekah Sapan ${ }^{4}$, Siti Aishah Ramli ${ }^{5}$, \\ Henry Bating ${ }^{6}$
}

1 PPIB, Universiti Malaysia Sabah, Malaysia Email: loick@ums.edu.my

2 PPIB, Universiti Malaysia Sabah, Malaysia Email: yokelian@ums.edu.my

3 PPIB, Universiti Malaysia Sabah, Malaysia Email: soon.chowthai@gmail.com

4 PPIB, Universiti Malaysia Sabah, Malaysia Email: nurshafiekah@ums.edu.my

5 PPIB, Universiti Malaysia Sabah, Malaysia Email: siti.aishah@ums.edu.my

6 PPIB, Universiti Malaysia Sabah, Malaysia Email:hbating@gmail.com

Corresponding Author

\section{Article Info:}

\section{Article history:}

Received date: 18.10 .2020

Revised date: 30.10 .2020

Accepted date: 15.11.2020

Published date: 03.03.2021

\section{To cite this document:}

Loi, C. K., Lau, Y. L., Soon, C. T., Sapan, N. S., Ramli, S. A., \& Bating, H. (2021). Rhetorical Strategies Used in Malay Research Article Conclusions. International Journal of Modern Trends in Social Sciences, 4 (15), 01-12.

\section{DOI: 10.35631/IJMTSS.415001}

This work is licensed under $\underline{\text { CC BY } 4.0}$

\section{(ㄷ)(1)}

\section{Abstract:}

This paper explains a combination of genre-based knowledge and evaluative stance in the context of academic arguments used in the conclusion sections of Malay research articles. For this purpose, it draws on an analysis of the features in Appraisal theory (Martin \& Rose, 2003) together with a move analysis (Swales, 1990, 2004). The data comprises empirical research articles. The conformity with the standard IMRD (Introduction- Method- ResultsDiscussion) is taken as the first similar feature when selecting the set of empirical research articles from the selected journals. Among others, the findings observe that evaluative stances produce rhetorical effects in Malay conclusions. When taking a stance, both the evoked Attitudes and inscribed Attitudes are employed. A closer examination shows that the evoked Attitudes and inscribed Attitudes are either used separately or simultaneously to realize a move.

Keywords:

Evaluative Stance, Conclusion, Malay, Research Articles, Rhetorical Effects 


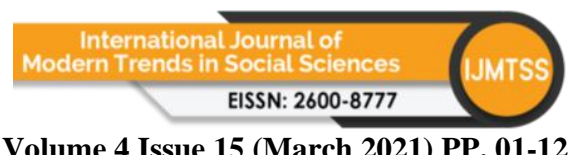

Volume 4 Issue 15 (March 2021) PP. 01-12 DOI 10.35631/IJMTSS.415001

\section{Introduction}

This paper explicates a range of rhetorical strategies employed by academic writers of Malay research articles in concluding their studies. It also demonstrates how evaluative stances have been employed to realize these strategies by drawing on an analysis of the features in Appraisal theory (Martin \& Rose, 2003) integrated with the analysis of communicative purposes within the genre analysis framework (Swales, 1990, 2004) (see the Methodology section for the description of the two frameworks).

This study extends the Malay data in Loi, Lim and Wharton (2016). In the study, a comparison was made between English and Malay research article conclusions in the evaluative stance and rhetorical strategies employed by authors of the two sets of data (English and Malay). On the other hand, the present study only focuses on the evaluative stance and rhetorical strategies employed by academic writers of Malay research articles (the Conclusion section) by extending the Malay data with additional insights and at the same time, compared to Loi, Lim and Wharton (2016), not looking into the Engagement element of Martin and Rose's (2003) Appraisal theory. The research questions addressed in the present study are as follows:

i. What are the rhetorical strategies used in Malay research article conclusions in terms of rhetorical moves and steps?

ii. In constructing writers' stances, how do Attitude and Graduation options co-articulate with each other to produce the rhetorical effects in (i)?

iii. Do writers of Malay research articles conclude their writing by using both the evoked and inscribed Attitudes?

iv. How do writers of Malay research articles present the evoked and inscribed Attitudes when taking a stance in relation to a communicative purpose (move)?

The purpose of the present study is therefore to extend the findings of the Malay data in Loi, Lim and Wharton (2016) by having these objectives: (i) to investigate the genre structure of Malay research article conclusions in terms of moves and steps using Swales's (1990, 2004) notion of genre analysis and (ii) to explore the evaluative stance used by writers of Malay research articles (the Conclusion section) using Martin and Rose's (2003) model of Appraisal.

\section{Literature Review}

\section{Theoretical Frameworks}

In Swales's (1990) theory which serves as one of the theoretical bases for the present research, move analysis provides the theoretical framework for analyzing texts. In move analysis, texts are conventionally divided into elements or stages, which represent the writers' communicative purposes. These stages are known as 'moves' (Swales, 1990, p. 141). A 'move' is, "the defined and bounded communicative act that is designed to achieve one main communicative objective" (Swales \& Feak, 2000, p. 35), and "a discoursal or rhetorical unit that performs a coherent communicative function in a written or spoken discourse" (Swales, 2004, p. 228).

Swales's studies (1990 \& 2004) show that a move can be further divided into sub-moves called 'steps'. A 'step' is defined by Swales (1990) as a smaller unit of discourse that builds moves (p. 142). In other words, each step supports and guarantees the validity of the move. 
The difference between a move and a step is that a move describes both the function and purpose of a segment of text, whereas a step details the rhetorical means of realizing the function of a move.

With regard to the overall organization of the three introductory moves in Swaless's (1990) CARS (Create a Research Space) model, in some cases, Move 1 and Move 2 might occur cyclically before Move 3 (e.g., move pattern of '1-2-3-1-2-3'), while in other cases Move 2 does not occur "immediately prior to the onset of Move 3" (Swales, 1990, p. 163) or in other words, there may be no Move 2 that could be related to Move 3 (e.g., move pattern of '1-3'). The cyclicity between Move 1 and Move 2, however, may occur after some paragraphs. Swales (1990) gave an example of cyclicity, which shows the cycles of Move 1 Step 3 and Move 2 Step 1B recur (p. 159).

The Appraisal theory (Martin \& Rose, 2003) identifies patterns of attitudinal choices that display the writers' stances, the force of these stances and their engagement options. Figure 1 (reproduced from Martin \& Rose, 2003) below illustrates the composition of these elements:

\begin{tabular}{|c|c|c|c|c|}
\hline & & Engagement $\rightarrow$ & $\begin{array}{l}\text { Mor } \\
\text { Hete }\end{array}$ & $\begin{array}{l}\text { Sss or } \\
\text { oss }\end{array}$ \\
\hline & & & Affe & \\
\hline Appraisal & $\rightarrow$ & Atticude & $\rightarrow$ & $\begin{array}{l}\text { Appreciation } \\
\text { Judgment }\end{array}$ \\
\hline & & Giraduation & $\begin{array}{l}\text { Forc } \\
\text { Focl }\end{array}$ & \\
\hline
\end{tabular}

Source: Martin \& Rose (2003)

\section{Figure 1: Appraisal Theory}

The category of Appreciation (appreciation of things) with positive/negative and inscribed/evoked dimension can be further sub-classified in terms of valuation, reaction and composition. Valuation codes the ideational (the content). Reaction codes the speaker/writer's interpersonal response while composition is concerned with the textual response (to the overall texture) (Eggins \& Slade, 1997, p. 128, as cited in Hood, 2004, p. 74).

In the present study, the term 'evoked' is generally used to mean that an attitudinal meaning can be interpreted although none is explicitly encoded (cf. Hood, 2004). In other words, the evoked Attitude implicitly encodes a value by employing Graduation. Graduation can be expressed in terms of high/low force or focus. In the present study, 'force' is further categorized into intensity (as a quality), quantity (as a thing) and enhancement (as a process) (adapted from Hood, 2004). 'Focus' is further categorized into focusing entities ('valeur' is the term used by Martin \& Rose, 2003). 'Focus: valeur' is interpreted in terms of authenticity and specificity (Hood, 2004). In the present study, the intensification of attitudinal attributes 


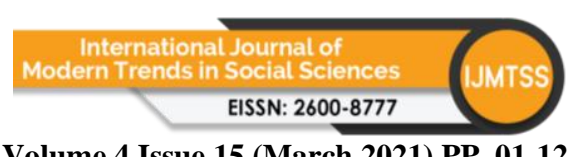

Volume 4 Issue 15 (March 2021) PP. 01-12 DOI 10.35631/IJMTSS.415001

(e.g., very efficient) can include the grading of attributes that inscribe a positive and negative value as well as those which do not inscribe a positive and negative value (e.g., limited research, few studies) (cf. Hood, 2004). 'Limited' and 'few' for example, retain some evaluative potential although each of the two words does not occur alongside an inscribed evaluative term (cf. Hood, 2004).

In the Engagement network (the present study does not include the analysis of this element), the category of contraction can be sub-classified as 'proclaim' and 'disclaim' while the category of expansion can be further classified in terms of 'attribute' and 'entertain'. The writers can draw on certain modality (e.g., modality of necessity such as 'should' which expresses a strong suggestion), projection and concession resources (Martin \& Rose, 2003, p.54) to contract the their own position and in contrast, the writers can draw on different modality, (e.g., modality of possibility such as 'may'/'could' which offers ideas as possible solution), projection and concession resources to entertain alternatives from the readers (cf. Chang \& Schleppegrell, 2011; Love \& Arkoudis, 2006).

\section{Past Studies Undertaken to Examine Communicative Purposes}

Some past studies involving Malay data have been conducted to examine the moves and steps found in academic discourse. One of which is Loi, Sweetnam Evans, Akkakoson, Shabbir Ahmed and Shameem Ahmed (2015)'s study. This study examines the communicative purposes (moves) used in Malay research article discussions in the field of education using Peacock's (2002) model. Some of the moves (more frequently-occurred moves followed by less frequently-occurred moves) are namely, Move 4 (Deduction), Move 2 (Findings), Move 5 (Reference to previous research), Move 1 (Information move), Move 8 (Implication), Move 10 (Recommendation), Move 7 (Significance of the study), Move 9 (Limitation) Move 3 ([(un)expected outcome] and Move 6 (Explanation- reasons for the expected/unexpected outcome).

Using a modified version of Peacock's (2002) model, Loi, Evan, and Lim (2016) compares between Malay and English research article discussions in the moves or communicative purposes used by the writers. Among some noteworthy findings of the Malay data are firstly, Malay discussions are more context dependent while English discussions are more context independent/standalone and secondly, Malay discussions fit Peacock's (2002) model partially compared with English discussions. In other words, Malay discussions share fewer similarities with the moves labelled in Peacock's (2002) model. The authors attribute the above phenomenon to the preference for rhetorical concepts and values in the local Malay writing community.

\section{Past Studies Undertaken to Examine Evaluative Stance}

However, research conducted to look at the evaluative stance in Malay academic discourse has been rare. To the best of the researchers' knowledge, except for Loi, Lim and Wharton (2016) which includes Malay data in the corpora to examine and compare the evaluative stance employed in Malay and English research article conclusions, no other research (as far as using the Appraisal theory to examine the evaluative stance is concerned), has looked into the Malay data. In Loi, Lim and Wharton (2013), among others, the findings show that both English and Malay data use evaluative stance. However, English research article conclusions contain a subtler balance of assertion and mitigations compared with Malay research article conclusions. According to the authors, their findings show that being in different scientific 


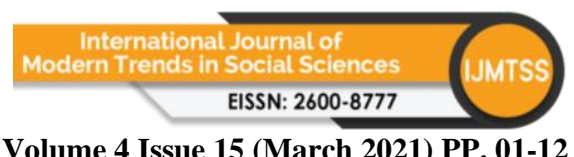

Volume 4 Issue 15 (March 2021) PP. 01-12

DOI 10.35631/IJMTSS.415001

communities (international and local), English and Malay scholars experience and value evaluation and the meaning potential of the genre differently.

Past studies relating to evaluative stance were mainly carried out to examine English texts. These studies looked at evaluative stance used in different contexts and discourses. $\mathrm{Wu}$ (2006) investigated undergraduate students' use contrastive stance through the strategy of problematization (Barton 1993). The author compared how writers of high-rated and lowrated essays problematized issues in more or less effective ways. It analysed the evaluative resources employed by the writers to achieve more or less successful problematization of issues discussed based on the engagement system of the Appraisal framework (Martin, 1992; Martin \& Rose, 2003; White, 1998). The findings indicated the writers of high-rated scripts used more strategic and appropriate evaluative resources to produce clear lines of contrastive positions. The study has pedagogical implications.

In a separate study conducted one year later, Harding (2007) argued that speakers often express attitudes not only toward events that have happened, but also toward counterfactual events. In her research, she analysed examples from different discourse situations that is from conversation to canonical literature. Her findings showed that counterfactuals and evaluations jointly produced rhetorical effects. Among others, an interesting finding showed that counterfactuals also encouraged readers to take a participatory role in the process of judgment.

In relation to academic discourse, Khamkhien (2014) examined the use of evaluative expressions in academic discourse based on the corpus-based approach. The findings showed that professional and experienced writers variably exploited stance markers. The study suggested that novice readers and writers to understand and use stance devices effectively to produce an academic prose. Stance markers found in the corpus included epistemic modality, extraposed 'it', communication verbs, and personal pronouns in terms of different functional types of evaluative stance. The study has pedagogical implications. It provides linguistic features that express evaluative stance used by academic writers of articles examined in the study. Among others, the findings contribute to improving an academic writing course and using practical language in the discourse community.

Among others, two most recent studies were carried out by Lam and Crosthwaite (2018) and Jing, Lei and Le (2020). Lam and Crosthwaite (2018) applied the appraisal model (Martin \& White, 2005) as part of a Contrastive Interlanguage Analysis (Granger, 1996, 2015) to compare the evaluative stance construed in L1 and L2 English texts. In the findings, generally L1 English writers showed that they were consistently depending on engagement resources and showing more dependence on these devices than L2 writers in their essays. However, L1 English writers used a significantly lower frequency of negative attitudes than Hong Kong L2 English writers. These contrastive corpus-informed results offered some insight into further evidence of differences in L1/L2 written evaluative stance and such information can contribute to effective writing instruction for learners.

On the other hand, Jing, Lei and Le (2020), examined the research trends in the field of evaluation, appraisal and stance. A bibliometric analysis was used to tabulate the findings. The findings showed an upward tendency in this research field as reflected in the substantial increase of the annual publications. Citation findings revealed that the most cited works included various sub-fields of linguistics and such findings showed the heterogenous nature Copyright (C) GLOBAL ACADEMIC EXCELLENCE (M) SDN BHD - All rights reserved 


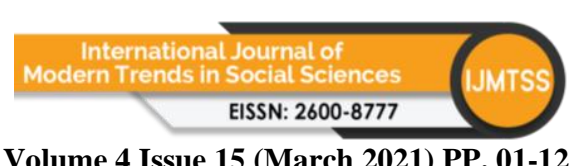

Volume 4 Issue 15 (March 2021) PP. 01-12

DOI 10.35631/IJMTSS.415001

of the evaluative aspect of language. Among others, the study suggested future research to explore the pedagogical applications of evaluation research.

\section{Methodology}

The selected research articles are from the field of psychology. The reason for the choice of the discipline represented in this study is that the discipline is among the fields the researchers are most familiar with. Having a fair background in the field has facilitated the reading and interpretation of the selected research articles. A total of 20 research article conclusions published between 2009 and 2014 were randomly chosen from the selected journals. The data was limited to empirical research articles. The articles which consisted of reviews and (re) interpretations of previous research were excluded. The conformity with the standard IMRD (Introduction- Method- Results- Discussion) was taken as the first similar feature in the selection of the set of empirical research articles from the selected journals. The Conclusion section is defined as the last section of a research article which is found after the 'Discussion' section or 'Results and Discussion' section.

The Malay articles were selected from two journals which include psychology articles. They are (i) Sosiohumanika: Jurnal Pendidikan Sains Sosial dan Kemanusiaan published by Association of Indonesian Scholars of History Education (ASPENSI) and (ii) e-Bangi published by the Faculty of Social Sciences and Humanities (FSSK), Universiti Kebangsaan Malaysia. The particular fields of interest in the selected Malay articles are educational psychology and social psychology. These Malay articles were written by academics who are attached to the department of psychology/the department of psychology and human development/health psychology unit at the higher institutions in Malaysia and Indonesia.

Swales's (1990 \& 2004) model of move analysis and Martin and Rose's (2003) Appraisal theory as described above have been used as the analysis frameworks for the present study. In stage one, the corpus was coded for the moves and steps found using Swales's framework of genre analysis. A model that comprised all the moves and steps coded in the corpus emerged after the coding. A quantitative analysis then was carried out to calculate the number of research articles (the conclusion sections) that contain the particular moves. The statistical data is in the form of percentage of conclusions /the number of conclusions that employs the particular moves. In stage 2 of the analysis, the rhetorical strategies coded were then analyzed to discover the evaluative stance used based on Martin and Rose's (2003) framework of evaluative stance (as elaborated in the literature review). For this paper, the identification of the evaluation stance was descriptive or qualitative in nature to discover the evaluative stance used by writers of Malay research articles to conclude their writing in their articles.

\section{Findings and Discussion}

Overall, Malay research article conclusions show the presence of three moves: Move 1 (summarizing the study), Move 2 (evaluating the study) and Move 3 (providing a deduction). These three moves and their respective steps occur cyclically rather than linearly (in a composite manner). Although it is not the aim of the present study to examine statistical data on the cyclicity of rhetorical moves/steps in Malay conclusion sections, it is worth noting that in past studies (e.g., Brett, 1994; Holmes, 1997; Hopkins \& Dudley-Evans, 1988; Loi, 2010, Loi \& Sweetnam Evans, 2010; Swales, 1990; Yang \& Allison, 2003), rhetorical moves/steps have been shown to be highly cyclical in research articles. 
Malay conclusions are more inclined to use Move 1 (summarizing the study) (85\%) compared to the other two moves, namely Move 2 (evaluating the study) (70.6\%) and Move 3 (providing a deduction) (55\%).

A higher number of step options employed in Move 2 (evaluating the study) compared to Move 1 (summarizing the study) and Move 3 (providing a deduction) of the conclusions, strongly indicates that the communicative focus (in terms of a wide range of rhetorical strategies) in the conclusions is primarily in the evaluative move (Move 2).

Writers of Malay research article conclusions use Attitude strategically in arguing/evaluating their own and past research in Move 1 (summarizing the study), Move 2 (evaluating the study) and Move 3 (providing a deduction).

The low force Graduation is found in instances of counter-claiming such as, to evoke the small amount of past research carried out on a particular research area or to evoke a limitation of past or present studies by accentuating a point [e.g., hanya menfokuskan/ only focus on (M2)].

The occurrences of low force Graduation to realize the above rhetorical effects in Malay conclusions are congruent with Malay conclusions employing the evaluative Move 2 (evaluating the study), that is, a functional move which contains these two rhetorical steps 'indicating a limitation' and 'providing a counter-claim'. The following exemplifies the above phenomenon:

[M2]: Ketiga, keputusan analisis regresi berganda hanya [evoked appreciation: valuationencoded in graduation low focus: valeur/specificity] menfokuskan kepada penerangan tentang varian tahap pretasi berdasarkan persamaan regresi (Tabachnick \& Fidell 2001), tetapi masih banyak lagi faktorefaktor lain yang penting perlu dimasukkan dalam analisis ... (Move 2 Step 3 - providing a counter-claim).

\{[M2]: Third, the results of multiple regression analysis only [evoked appreciation: valuation- encoded in graduation low focus: valeur/specificity] focus on the description of the variant level of performance based on the regression equation (Tabachnick \& Fidell, 2001), but there are still many more other factors that are important to be included in the analysis ... (Move 2 Step 3 - providing a counter-claim).

In the Malay corpus, M3 and M14 below, show that evoked instead of inscribed Attitudes are used when taking a stance in relation to the findings of the study (e.g., in M3, 'kebanyakan remaja hamil luar nikah mempunyai ...' / 'most teenagers who are pregnant out of wedlock have ...' and in M14, 'sebahagian besar...majoriti'/ 'largely... majoriti') :

[M3]: Dapatan kajian memperlihatkan bahawa kebanyakan [evoked appreciation: valuation encoded in graduation high force: quantity] remaja hamil luar nikah mempunyai latar belakang keluarga yang kurang [evoked appreciation: valuation encoded in graduation low force: intensity] sempurna [inscribed appreciation: valuation] ... (Move 1 Step 1- presenting overall findings).

\{[M3]: The findings show that most [evoked appreciation: valuation encoded in graduation high force: quantity] teenagers who are pregnant out of wedlock have less Copyright $\odot$ GLOBAL ACADEMIC EXCELLENCE (M) SDN BHD - All rights reserved 


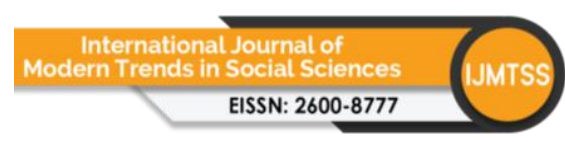

Volume 4 Issue 15 (March 2021) PP. 01-12 DOI 10.35631/IJMTSS.415001

[evoked appreciation: valuation encoded in graduation low force: intensity] ideal [inscribed appreciation: valuation] family background ... (Move 1 Step 1- presenting overall findings).

[M14]: Belia di Muar juga menyokong aspirasi kerajaan dalam memantapkan agenda pembangunan belia negara dan sebahagian besarnya [evoked appreciation: quantity] menyatakan bahawa gagasan 1 Malaysia: 'Rakyat Didahulukan, Pencapaian Diutamakan' disokong, dihayati dan dimanifestasikan oleh generasi muda [inscribed appreciation: composition]. Dari aspek governans pula, majoriti [evoked appreciation: quantity] menyatakan Indeks Petunjuk Prestasi (KPI) untuk wakil rakyat dan Menteri adalah baik [inscribed appreciation: valuation] dan mempengaruhi sokongan rakyat terhadap kerajaan dan... (Move 1 Step 1- presenting overall findings).

\{[M14]: Youth in Muar also support the government's aspiration to strengthen the agenda of the development of the country's youth and largely [evoked appreciation: quantity] states the idea of ' 1 Malaysia: People are placed First, Achievement is prioritized'\| is supported, appreciated and endorsed by the younger generation [inscribed appreciation: composition]. On the other hand, the majority [evoked appreciation: quantity] state that the Index of Performance Indicators (KPIs) for the representatives of the people and the Minister is good [inscribed appreciation: valuation] and affects the people's support for the government and ... (Move 1 Step 1- presenting overall findings).

On the other hand, M5 and M16 show that an overt and amplified attitudinal stance instead of an implicit one is used when commenting on an aspect related to the field as a domain. For example, in M5, when the writer comments about the global issue of sexual abuse (e.g., 'penderaan seksual ... dan tidak mustahil berlaku ... '/'sexual abuse ... and it is not impossible to happen ... ' while in M16, when the writer comments on the personalities and qualities prisoners should/should not possess (e.g., 'sifat-sifat terpuji'/ 'praiseworthy traits'; 'sifat-sifat tercela'/'degrading traits'; 'seorang yang produktif dan berakhlak mulia'/ 'someone who is productive and has virtuous character') after they have been released from the jail to live in the community. The inscribed Attitudes seem to be used by the Malay writers to overtly and explicitly express an attitudinal stance to highlight the importance of the issues. These two examples are presented below:

[M5]: Penderaan seksual [inscribed appreciation: composition] merupakan isu sejagat [inscribed appreciation: composition]. Mangsanya adalah kanak-kanak, remaja, individu dewasa, dan tidak mustahil [inscribed appreciation: valuation] berlaku juga kepada warga tua [inscribed appreciation: composition] (Move 1 Step 1-presenting overall findings).

\{[M5]: Sexual [inscribed appreciation: composition] abuse is a global [inscribed appreciation: composition] issue. The victims include children, adolescents, individual adults, and it is not impossible [inscribed appreciation: valuation] to happen to the elderly [inscribed appreciation: composition] people as well (Move 1 Step 1- presenting overall findings).

[M16]: Selain itu ia juga membolehkan banduan mengamalkan sifat-sifat yang terpuji [inscribed appreciation:valuation] dan menjauhi sifat yang tercela [inscribed appreciation: valuation] sehingga mampu membimbing mereka untuk kembali kepada masyarakat sebagai seorang yang produktif [inscribed appreciation:valuation] dan Copyright (C) GLOBAL ACADEMIC EXCELLENCE (M) SDN BHD - All rights reserved 
berakhlak mulia [inscribed appreciation:valuation] (Move 1 Step 1- presenting overall findings).

\{[M16]: It also enables prisoners to practise praiseworthy [inscribed appreciation:valuation] traits and avoid degrading [inscribed appreciation:valuation] traits till it is able to guide them to return to the society as people who are productive [inscribed appreciation:valuation] and have virtuous [inscribed appreciation:valuation] character (Move 1 Step 1- presenting overall findings).

In the Malay corpus, writers also use both the evoked and inscribed Attitudes simultaneously when taking a stance in relation to Move 2 (evaluating the study) by indicating the significance (M15), providing an explanation (M11) and a pedagogical/theoretical implication (M8) as shown in the following examples:

[M15]:Maka guru dan kakitangan sekolah terutamanya [evoked appreciation: valuation] pekerja sosial sekolah merupakan pihak yang amat penting [inscribed appreciation: valuation] dalam membantu menangani pencegahan awal [inscribed appreciation: composition] kes penderaan dan pengabaian kanak-kanak (Move 2 Step 1 - indicating the significance).

\{[M15]: Therefore, school teachers and staff, especially [evoked appreciation: valuation] the school social workers, are very important [inscribed appreciation: valuation] in helping to deal with the early [inscribed appreciation: composition] prevention of child abuse and child neglect cases (Move 2 Step 1 - indicating the significance).

[M11]: Perhubungan dan bimbingan ibu bapa yang baik [inscribed appreciation: valuation] dengan anak mampu [evoked appreciation: valuation] mendidik dan membentuk personaliti anak dengan baik [inscribed appreciation: valuation]. Namun demikian sokongan guru, rakan dan rakan sekelas juga tidak boleh diabaikan kerana ia juga dilihat mampu [evoked appreciation: valuation] mempengaruhi penghargaan kendiri remaja sekolah apabila remaja sekolah berhadapan masalah tekanan di rumah, sekolah mahupun komuniti (Move 2 Step 5- providing an explanation).

\{[M11]: Good [inscribed appreciation: valuation] parenting relationships and guidance educate and shape the child's personality well [inscribed appreciation: valuation]. However, the support of teachers, friends and classmates cannot be neglected as it is also seen as being able to [evoked appreciation: valuation] influence school teenaged selfesteem when school children are facing stress at home, school or community (Move 2 Step 5providing an explanation). $\}$

[M8]: Oleh itu, maka wajar [evoked appreciation: valuation] satu tindakan drastik [inscribed appreciation: composition] diambil oleh pihak PUSPEN khasnya [evoked appreciation: valuation] untuk memantapkan tingkahlaku dan jatidiri penagih melalui proses rawatan dan pemulihan yang disediakan (Move 3 Step 1- Providing a pedagogical/theoretical implication).

\{[M8]: Therefore, it is appropriate [evoked appreciation: valuation] that a drastic action [inscribed appreciation: composition] is taken by PUSPEN especially [evoked appreciation: valuation] to strengthen the behaviour and identity of the addicts through the 


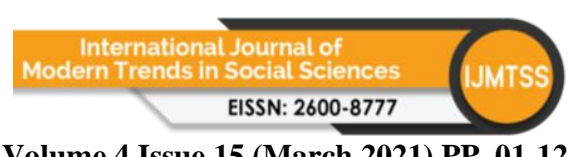

Volume 4 Issue 15 (March 2021) PP. 01-12

DOI 10.35631/IJMTSS.415001

treatment and recovery process provided (Move 3 Step 1- Providing a pedagogical/theoretical implication).\}

In sum, the above findings show that evaluative stance is used with an emphasis put on the evoked attitude/inscribed attitude/a combination of both the evoked and inscribed attitudes. One possible reason for using such rhetorical strategies is to jointly produce the rhetorical effects to realize the communicative purposes (moves) in the conclusions.

\section{Conclusion}

The study has attempted to look into the use of rhetorical strategies realized by a combination of genre-based knowledge and evaluative stance in the context of academic arguments in the conclusion sections of Malay research articles. As stated above, for this purpose, it draws on an analysis of the features in Appraisal theory (Martin \& Rose, 2003) together with an analysis of communicative purposes within a genre analysis framework (Swales, 1990, 2004).

In the present findings, it is seen that the discursive activities rest heavily on the writers' manipulation of two linguistic resources (Attitudes and Graduation) to create a convincing stance as perceived by members of the discourse communities. In the conclusions, writers navigate the reader by aligning their works with the meta-evaluation thus, signaling that their study is warranted or worthwhile. This is reflected in the employment of Move 2 Step 1 (indicating significance) and Move 3 Step 1 (providing a pedagogical/theoretical implication).

In general, Malay research article conclusions use three moves, namely Move 1 (summarizing the study) or/and Move 2 (evaluating the study) or/and Move 3 (providing a deduction). When taking a stance, both the evoked Attitudes and inscribed Attitudes are employed. A closer examination shows that the evoked Attitudes and inscribed Attitudes are either used separately or simultaneously to realize a move (see examples presented in the above Findings and Discussion section) (cf. Loi, Lim \& Wharton, 2016).

The above findings show how rhetorical meanings are achieved and reinforced by writers as a result of co-articulation of the linguistic resources employed (cf. Chang \& Schleppegrell, 2011). In other words, evaluative stance (Attitudes) and force of the stance (Graduation) jointly produce the rhetorical effects in the conclusions.

This study uses a relatively small corpus (20 conclusions) to explore the evaluative stance employed by the writers of Malay research articles by focusing on the Conclusion section thus, the present study does not aim to generalize the findings to an entire discipline of psychology. However, the findings allow writing instructors to make informed pedagogical decisions that are grounded in the understanding of the rhetorical strategies, to guide Malay ESL (English as a Second Language) students in producing acceptable and comprehensible arguments in academic writings.

\section{References}

Barton, E. L. (1993). Evidentials, argumentation, and epistemological stance. College English 5(7), 745-769.

Brett, P. (1994). A genre analysis of the result section of sociology articles. English for Specific Purposes, 13(1), 47-59. 


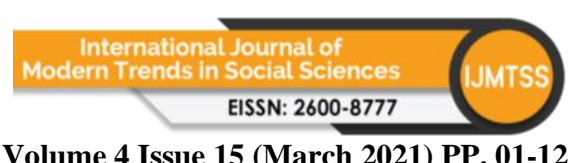

Volume 4 Issue 15 (March 2021) PP. 01-12

DOI 10.35631/IJMTSS.415001

Chang, P., \& Schleppegrell, M. (2011). Taking an effective authorial stance in academic writing: making the linguistic resources explicit for L2 writers in the social sciences. Journal of English for Academic Purposes, 10, 140-151.

Eggins, S., \& Slade, D. (1997). Analyzing casual conversation. London: Cassell.

Granger, S. (1996). From CA to CIA and back: an integrated approach to computerized bilingual and learner corpora. In K. Aijmer, B. Altenberg, \& M. Johansson. (Eds.), Languages in contrast. papers from a symposium on text-based cross-linguistic studies (pp. 37-51). Lund: Lund University Press.

Granger, S. (2015). Contrastive interlanguage analysis. International Journal of Learner Corpus Research, 1(1), 7-24.

Harding, J. R. (2007). Evaluative stance and counterfactuals in language and literature. Language and Literature: International Journal of Stylistics, 16(3), 263-280. https://doi.org/10.1177/0963947007079109

Holmes, R. (1997). Genre analysis and the social sciences: an investigation of the structure of research article discussion sections in three disciplines. English for Specific Purposes, 16(4), 321-337.

Hood, S. (2004). Appraising research: Taking a stance in academic writing (Unpublished PhD thesis). Sydney: Faculty of Education, University of Technology.

Hopkins, A., \& Dudley-Evans, T. (1988). A genre-based investigation of the discussion sections in articles and dissertations. English for Specific Purposes, 7(2), 113-122.

Jing, L., Lei, L., \& Le, C. (2020). Mapping evaluation, appraisal and stance in discourse (2000-2015): A bibliometric analysis. Glottotheory, 10(1-2), 31-55.

Khamkhien, T. A. (2014). Linguistic features of evaluative stance: Findings from research article discussions. Indonesian Journal of Applied Linguistics, 4(1), 54-69.

Lam, S. L., \& Crosthwaite, P. (2018). Appraisal resources in L1 and L2 argumentative essays: A contrastive learner corpus-informed study of evaluative stance. Journal of Corpora and Discourse Studies, 1 (1), 8-35.

Loi, C. K. (2010). Research article introductions in Chinese and English: A comparative genre-based study. Journal of English for Academic Purposes, 9(4), 267-279.

Loi, C.K., Lim, J.M.H., \& Wharton, S. (2016). Expressing an evaluative stance in English and Malay research article conclusions: International publications versus local publications. Journal of English for Academic Purpose, 21, 1-16.

Loi, C. K., \& Sweetnarn Evans, M. (2010). Cultural differences in the organization of research article introductions from the field of educational psychology: English and Chinese. Journal of Pragmatics, 42(10), 2814-2825.

Loi, C.K., Sweetnam Evans, M., Akkakoson, S., Shabbir Ahmad, \& Shameem Ahmad (2015). Rhetorical patterns in the discussion sections of Malay research articles. International Journal of Languages, Literature and Linguistics, 1(2), 118-121.

Loi, C. K., Sweetnam Evans, M., Lim, J. M. H. \& Akakoson, S. (2016). A comparison between Malay and English research article discussions: A move analysis. Sage Open, April-June 2016: 1-11. DOI: 10.1177/2158244016652925.

Love, K., \& Arkoudis, S. (2006). Teachers' stances towards Chinese international students: an Australian case study. Language and Education, 17, 258-282.

Martin, J. R. (1992). English Text: System and Structure (Amsterdam: John Benjamins ).

Martin, J. R., \& Rose, D. (2003). Working with discourse: Meaning beyond the clause. London: Continuum.

Martin, J.R. \& White, P.R.R. (2005). The language of evaluation: appraisal in English. Basingstoke \& New York, NY: Palgrave Macmillan. 
Peacock, M. (2002). Communicative moves in the discussion section of research articles. System, 30, 479-497.

Swales, J. M. (1990). Genre analysis. English in academic and research settings. Cambridge, UK: Cambridge University Press.

Swales, J. M. (2004). Research genres. exploration and applications. Cambridge, UK: Cambridge University Press.

Swales, J. M., \& Feak, C. B. (2000). English in today's research world: A writing guide. Ann Arbor, MI: University of Michigan Press.

White, P. (1998). Telling media tales: The news story as rhetoric (unpublished $\mathrm{PhD}$ dissertation, University of Sydney).

$\mathrm{Wu}, \mathrm{S}$. M. (2006). Creating a contrastive rhetorical stance: Investigating the strategy of problematization in students' argumentation. RELC Journal, 37(3):329-353. doi:10.1177/0033688206071316

Yang, R., \& Allison, D. (2003). Research articles in applied linguistics: Moving from results to conclusions. English for Specific Purposes, 22(4), 365-385. 